\title{
Survival of Lactobacillus rhamnosus probiotic strains in peach jam during storage at different temperatures
} Cinzia Lucia RANDAZZO ${ }^{1}$, Iole PITINO ${ }^{1}$, Fabio LICCIARDELLO ${ }^{2 *}$, Giuseppe MURATORE², Cinzia CAGGIA ${ }^{1}$

\begin{abstract}
The survival of six probiotic wild strains of Lactobacillus rhamnosus was compared with that of a type strain during 78 days of storage at 25 and $5{ }^{\circ} \mathrm{C}$ in peach synthetic medium (PSM) and commercial peach jam (PJ). Changes in viable cell counts, pH values, sugar content, and colour parameters were monitored. All strains exhibited better performances in PJ than in PSM, showing count values higher than $7 \mathrm{Log} \mathrm{cfu} \mathrm{g}^{-1}$ up to 78 days of storage at $5^{\circ} \mathrm{C}$. Almost all wild strains remained above the critical value of $6 \mathrm{Log} \mathrm{cfu}^{-1}$ in samples stored at $25^{\circ} \mathrm{C}$ up to 45 days, while the Lb. rhamnosus GG type strain, used as control, was not able to survive later than 15 days. In the synthetic medium used, the strains showed better survival in the samples incubated at $25^{\circ} \mathrm{C}$, remaining viable above the critical level up to 45 days of storage, except for the strain H12. The probiotic cultures added to jam did not significantly change the colour parameters of the product; however the metabolism of lactobacilli did cause changes in the $\mathrm{pH}$ and in the composition of sugars.
\end{abstract}

Keywords: Lactobacillus rhamnosus; jam; probiotics; quality indices.

\section{Introduction}

Probiotics are live microorganisms that confer a health benefit on the host when administered in adequate amounts (FOOD...; WORLD..., 2002). In recent years, the proposed health benefit of probiotics has undergone increasingly rigorous scientific evaluation and, at present, strong evidences for their use in treating and preventing some human diseases have been proved. They are considered effective in the treatment of infantile diarrhoea, traveler's diarrhoea, and antibioticassociated diarrhoea, paucities, inflammatory bowel disease, urogenital infections, and ulcer (MORENO et al., 2006; MCFARLAND, 2007), and they are active to prevent food allergy and hypercholesterolemia (SALMINEN et al., 1998; CROSS; STEVENSON; GILL, 2001; SAARELA et al., 2002). Most probiotics in use today belong to the genera Lactobacillus and Bifidobacterium. Within these genera, most species, such as Lactobacillus rhamnosus, have received the Qualified Presumption of Safety (QPS) status (EUROPEAN..., 2007) and, having a long history of safety use, are considered to be GRAS (Generally Recognised as Safe) (TAMIME, 2002; DE VUYST; AVANTI; MAKRAS, 2004; MATTIA; MERKER, 2008). Recently, new species and specific strains belonging to the genus Lactobacillus have been continuously identified as probiotics (VANCANNEYT et al., 2006) since it is known that the health benefit imparted by probiotic microorganisms are strain specific.

Although probiotics have traditionally been added to yogurt and other fermented dairy products (LAROIA; MARTIN, 1991; LOURENS-HATTINGH; VILJOEN, 2001; PENNA; RAOGURRAM; BARBOSA-CÁNOVAS, 2007), nowadays there has been an increasing demand for non-dairy probiotic products, and these organisms have been incorporated into drinks, as well as marketed as supplements in the form of tables, capsules, and freeze-dried preparation (SCHREZENMEIR; DE VRESE, 2001; BERNI-CANANI et al., 2007). When probiotics are added into a new probiotic food or drink, many important variables must be considered in order to guarantee viability, which is considered essential for their health benefits. The physiologic state of the probiotics added to food is of considerable importance, and it very much depends on the time of harvesting of the culture (whether during the logarithmic or stationary phase of growth), on the condition leading to transition to the stationary phase, on the treatment of the probiotics during and after harvesting, and, finally, on the composition of the growth medium in relation to the composition of the food to which they will be added. Thus, probiotic foods or preparations should have an extended shelf life so that they can contain a large number of viable cells at the time of consumption (typically at least $10^{6} \mathrm{cfu} / \mathrm{g}$ of product) (OUWEHAND; SALMINEM, 1998).

They also should survive in the human gastric juice to reach the small intestine and the colon (SANDERS; HIUS IN'T VELD, 1999). The main factors affecting the probiotic survival in the consumer's GI tract are the physicochemical parameters of the food matrix involved, such as carbon and nitrogen contents, $\mathrm{pH}$, water activity, and the physical conditions during storage (RIVERA-ESPINOZA; GALLARDO-NAVARRO, 2010) such as the immobilization of probiotic cells within an encapsulating matrix (DING; SHAH, 2007).

As mentioned above, current industrial probiotic foods are basically dairy products, which may represent inconveniences due to their lactose and cholesterol content (HEENAN et al., 2004). Recently, new formulates such as fruit juices, cereals, chocolate, ice cream, and desserts appear to be good vehicles

Received 5/24/2013

Accepted 8/19/2013 (006105)

${ }^{1}$ Department of Agri-food and Environmental Systems Management - DiGeSA, University of Catania, via Santa Sofia, 98,95123 Catania, Italy

${ }^{2}$ Department of Agricultural and Food Science - DiSPA, University of Catania, via Santa Sofia, 98, 95123 Catania, Italy, e-mail: fabio.licciardello@unict.it

${ }^{*}$ Corresponding author 
for delivering probiotics to humans (CORBO et al., 2001; LAVERMICOCCA, 2006; CRUZ et al., 2009). In this scenario, the combinations of probiotic strains with fruit, already positioned as a healthy food product, could be very successful, and the consumption of probiotics could be extended to certain segments of the population such as vegetarians, children, and those who are allergic to dairy products (LUCKOW; DELAHUNTY, 2004). Researchers have reported that the cell viability in fruit matrices depends on the strains used, the characteristic of the substrate, the oxygen content, and the final acidity of the product.

The aim of the present study was to examine the survival of probiotic Lb. rhamnosus strains both in synthetic media and in peach jam during storage (till to 78 days) at $25^{\circ} \mathrm{C}$ and at $5{ }^{\circ} \mathrm{C}$.

\section{Materials and methods}

\subsection{Peach synthetic medium}

In order to simulate peach jam formulation, a Synthetic Peach Medium (SPM) was developed for evaluating growth/ survival of Lb. rhamnosus strains. The composition of the medium was as follow: $11 \mathrm{~g}$ of sucrose; $0.3 \mathrm{~g}$ agar, and $100 \mathrm{~mL}$ of concentrated peach juice. The $\mathrm{pH}$ of medium was corrected to 4.5 by adding food grade lactic acid (Carlo Erba, Milan, Italy). The medium was dispensed into sterilized vessels and kept at 5 and $25^{\circ} \mathrm{C}$ prior to strain inoculation.

\subsection{Peach jam samples}

The jam used in the present study was kindly provided by a local company producing peach jam from organic-farmed peaches (Prunus persica L. Batsch), the "Late Peaches of Leonforte" cultivated in Sicily (Italy), object of a previous study (RESTUCCIA et al., 2006). The jam was obtained following regular industrial run. Peach (80\%), saccharose (18\%), and fresh lemon juice (2\%) were mixed and heated at $40-45^{\circ} \mathrm{C}$ to have a final ${ }^{\circ} \mathrm{Brix}$ value of $38-40$. The jam was dispensed $(340 \mathrm{~g}$ serving) into glass vessels and regularly processed. No additive was added to the jam.

\subsection{Bacterial strains}

In the present study, 6 wild strains belonging to DiGeSa (University of Catania, Italy) microbial collection were used. The strains were previously isolated from traditional Pecorino cheese and identified for phenotypical, genotypical, biochemical, and technological properties (PITINO et al., 2009; RANDAZZO; PITINO; CAGGIA, 2009; RANDAZZO et al., 2009). The strains were also previously studied for their probiotic attributes such as tolerance to low $\mathrm{pH}$, bile pancreatic juice; biofilm synthesis; ability to adhere to both the intestinal epithelium cell line Caco-2 cells and HT-29 cells, antibiotic susceptibility (PITINO et al., 2009; RANDAZZO; PITINO; CAGGIA, 2009; RANDAZZO et al., 2009), and survival capacity during in vitro dynamic gastrointestinal digestion with DGM using MRS broth medium and cheese as vehicles (PITINO et al., 2012; PITINO, 2010). The Lb. rhamnosus GG ATCC53103 (LGG) strain was used as control.
All strains were grown in MRS medium (Oxoid, Milan, Italy) and stored with $20 \%$ glycerol at $-80{ }^{\circ} \mathrm{C}$ until use.

\subsection{Preparation and inoculation of probiotic cultures into peach synthetic medium}

The Lb. rhamnosus strains were reactivated by sub-culturing twice in MRS broth overnight at $37^{\circ} \mathrm{C}$ from a $1 \%(\mathrm{v} / \mathrm{v})$ stock inoculum. All cultures were harvested (10,000 rpm, 10 minutes), washed, re-suspended in physiological water $(0.9 \% \mathrm{w} / \mathrm{v} \mathrm{NaCl})$, and concentrated 10 -fold in the same diluent. A $1 \%$ inoculum of each probiotic culture was distributed into the PSM to obtain a final concentration of $10^{9} \mathrm{cfu} / \mathrm{g}$. Peach synthetic medium inoculated with physiological water $(0.9 \% \mathrm{w} / \mathrm{v} \mathrm{NaCl})$ was used as control. All obtained samples were stored at $5{ }^{\circ} \mathrm{C}$ and $25^{\circ} \mathrm{C}$.

\subsection{Inoculation of probiotic cultures into commercial jam}

Commercial jars of jam were opened under aseptic conditions, and portions of jam (100 g) were dispensed into sterilized tubes. Each tube was inoculated with fresh probiotic culture, described above, to obtain a final concentration of $10^{9}$ $\mathrm{cfu} / \mathrm{g}$ of fruit jam. The cell suspensions were gently mixed with the jam and stored at $5{ }^{\circ} \mathrm{C}$ and $25^{\circ} \mathrm{C}$. Peach jam inoculated with physiological water $(0.9 \% \mathrm{w} / \mathrm{v} \mathrm{NaCl})$ was used as control.

\subsection{Physicochemical analyses of samples}

The $\mathrm{pH}$ values were measured with a $\mathrm{pH}$ meter at regular intervals. For the measurement of the physicochemical parameters, the samples were collected on the same day of production and after 78 days of storage at 5 and $25^{\circ} \mathrm{C}$.

Sugar content was measured using the enzymatic assay kit Sucrose/D-fructose/D-glucose (K-SUFRG) (Megazyme International Ireland Ltd, Wiclkow), following the manufacturer's instructions.

The colour parameters (CIE L* $\mathrm{a}^{*} \mathrm{~b}^{*}$ ) and browning index were evaluated as described by Licciardello and Muratore (LICCIARDELLO; MURATORE, 2011).

\subsection{Enumeration of probiotic bacteria}

In order to enumerate the viable probiotic bacteria, aliquots of SPM and PJ, un-inoculated and inoculated with both wild and LGG strains were taken at regular intervals $(0,15,30$, 45 , and 78 days of storage at 5 and $25^{\circ} \mathrm{C}$ ). Ten grams of each sample were aseptically mixed with $90 \mathrm{~mL}$ of physiological salt solution ( $\mathrm{pH} 7.0 ; 0.9 \% \mathrm{NaCl}$ and $1.0 \%$ Bacto Peptone from Oxoid) using a stomacher filtered bag (Bagfilter, Interscience, Saint-Nom, France), and the filtered liquid phase, serially diluted in a physiological solution, was plated in duplicate onto Plate Count Agar (Oxoid), incubated at $25^{\circ} \mathrm{C}$ for 24 hours, and onto MRS agar (Merck) at $37^{\circ} \mathrm{C}$ for 48 hours under anaerobic conditions using anaerobic gas jars containing Anaerocoult A gas pack (Oxoid). Typical colonies grown in MRS agar plates were randomly selected and confirmed as Lb. rhamnosus by further tests (including Gram staining, catalase). 


\subsection{Statistical analysis}

All data were submitted to one-way analysis of variance (ANOVA), and post-hoc comparison of means was performed by the Tukey test $(\mathrm{p}<0.05)$ using the statistical package $\mathrm{IBM}^{\circledast}$ SPSS ${ }^{\oplus}$ Statistics 13.0 (Armonk, NY, USA).

\section{Results}

\subsection{Physicochemical parameters of peach synthetic medium and jam samples}

The change in $\mathrm{pH}$ values in PSM and jam, non-inoculated (control) and inoculated with the 6 wild strains and the LGG strain, during storage at 5 and $25^{\circ} \mathrm{C}$, is reported in Table 1 . An overall decrease in the $\mathrm{pH}$ of all the samples occurred during refrigerated storage.

Following the trend of $\mathrm{pH}$ in PSM, the control showed a slight decrease during storage at both temperatures. The PSM inoculated with LGG strain exhibited a decrease throughout storage at different temperatures, reaching the lowest $\mathrm{pH}$ value after 30 days at $25^{\circ} \mathrm{C}$. Interestingly, PSM samples inoculated with wild strains showed, at $25^{\circ} \mathrm{C}, \mathrm{pH}$ values quite similar to those obtained by LGG strain. In particular, the PSM inoculated with wild strains exhibited a significant decrease during storage at $25^{\circ} \mathrm{C}$ reaching values between 3.00 and 3.40 after 78 days. A different $\mathrm{pH}$ trend was observed in PSM inoculated with wild strains incubated at $5^{\circ} \mathrm{C}$. PSM samples inoculated with $\mathrm{H} 25$, $\mathrm{N} 34$, D34, and D13 strains showed a slight increase in $\mathrm{pH}$ values throughout storage, except for PSM inoculated with R61 strain, which exhibited quite constant $\mathrm{pH}$ values, and PSM inoculated with $\mathrm{H} 12$, which showed a significant $\mathrm{pH}$ decrease.

Evaluating the $\mathrm{pH}$ changes in $\mathrm{PJ}$, the control showed a decrease during storage both at 5 and $25^{\circ} \mathrm{C}$. In PJ inoculated with all wild strains, including LGG strain, an overall decrease in $\mathrm{pH}$ occurred during storage at $25^{\circ} \mathrm{C}$. The largest $\mathrm{pH}$ decrease was observed in the sample inoculated with D13 wild strain ( $\mathrm{pH}$ value of 3.26 after 78 days). A similar trend was observed in PJ samples inoculated with wild strains and incubated at 5 ${ }^{\circ} \mathrm{C}$. PJ samples inoculated with the LGG strain showed a more pronounced decrease reaching the lowest $\mathrm{pH}$ value (3.80) after 30 days.

The total sugar content, evaluated at the end of storage and expressed as g/100 $\mathrm{g}$ of D-glucose, D-fructose, and sucrose, of PJ non-inoculated and inoculated with LGG and wild strains is shown in Figure 1. Freshly prepared PJ samples had the following sugar composition: 3.39 and 5.18/100 g of glucose and fructose, respectively, and 19.21/100 g of sucrose.

The total sugar content remained quite constant in the control samples stored at 5 and $25^{\circ} \mathrm{C}$ (Figure 1), whereas the glucose+fructose/sucrose ratio changed during storage. In particular, the sucrose levels decreased after 78 days of storage, while the glucose and fructose concentrations increased. Moreover, it is worth noting that the sucrose decrease took place faster at 25 than at $5{ }^{\circ} \mathrm{C}$. Sugar contents in the PJ sample inoculated with LGG strain showed values comparable with those of the control, both at 5 and $25^{\circ} \mathrm{C}$. Samples stored at $25^{\circ} \mathrm{C}$ inoculated with the wild strains, except for $\mathrm{H} 12$ and N34, showed a decrease in total sugar content at the end of storage.

Table 1. pH values in Peach Synthetic Medium (PSM) and in Peach Jam (PJ) samples inoculated with Lb. rhamnosus strains at different storage temperatures $\left(25\right.$ and $\left.5^{\circ} \mathrm{C}\right)$.

\begin{tabular}{|c|c|c|c|c|c|c|c|c|c|c|}
\hline & & Days & $\begin{array}{c}\text { Control } \\
\text { (non-inoculated) }\end{array}$ & LGG & R61 & $\mathrm{H} 25$ & $\mathrm{H} 12$ & N34 & D34 & D13 \\
\hline \multirow{7}{*}{ PSM - } & \multirow{4}{*}{$25^{\circ} \mathrm{C}$} & 0 & $4.50 \pm 0.07 \mathrm{~b}$ & $4.50 \pm 0.60 c$ & $4.51 \pm 0.57 \mathrm{~b}$ & $4.38 \pm 0.02 b$ & $4.58 \pm 0.06 \mathrm{~b}$ & $4.38 \pm 0.23 b c$ & $4.42 \pm 0.24 \mathrm{c}$ & $4.39 \pm 0.02 b$ \\
\hline & & 15 & $4.06 \pm 0.16 \mathrm{a}$ & $3.83 \pm 0.72 b$ & $3.73 \pm 0.55 \mathrm{ab}$ & $3.49 \pm 0.12 \mathrm{a}$ & $3.64 \pm 0.05 \mathrm{a}$ & $4.19 \pm 0.01 \mathrm{~b}$ & $3.42 \pm 0.13 \mathrm{~b}$ & $3.80 \pm 0.15 \mathrm{ab}$ \\
\hline & & 45 & $4.03 \pm 0.16 \mathrm{a}$ & $3.35 \pm 0.22 \mathrm{ab}$ & $3.44 \pm 0.51 \mathrm{a}$ & $3.34 \pm 0.14 \mathrm{a}$ & $3.46 \pm 0.12 \mathrm{a}$ & $3.47 \pm 0.15 \mathrm{a}$ & $3.24 \pm 0.09 \mathrm{~b}$ & $3.39 \pm 0.26 \mathrm{a}$ \\
\hline & & 78 & $4.38 \pm 0.08 \mathrm{ab}$ & $3.30 \pm 0.42 \mathrm{ab}$ & $3.35 \pm 0.57 \mathrm{a}$ & $3.30 \pm 0.24 \mathrm{a}$ & $3.44 \pm 0.02 \mathrm{a}$ & $3.41 \pm 0.20 \mathrm{a}$ & $3.10 \pm 0.07 \mathrm{a}$ & $3.00 \pm 0.40 \mathrm{a}$ \\
\hline & \multirow[t]{3}{*}{$5^{\circ} \mathrm{C}$} & 30 & $4.32 \pm 0.13 \mathrm{ab}$ & $3.56 \pm 0.14 \mathrm{a}$ & $4.53 \pm 0.28$ & $4.52 \pm 0.15 b$ & $4.21 \pm 0.20 \mathrm{~b}$ & $4.44 \pm 0.21 \mathrm{a}$ & $4.57 \pm 0.25 \mathrm{ab}$ & $4.39 \pm 0.12 \mathrm{a}$ \\
\hline & & 45 & $4.30 \pm 0.12 \mathrm{ab}$ & $3.67 \pm 0.14 \mathrm{a}$ & $4.47 \pm 0.34$ & $4.49 \pm 0.38 \mathrm{ab}$ & $4.15 \pm 0.02 \mathrm{a}$ & $4.44 \pm 0.08 \mathrm{a}$ & $4.54 \pm 0.17 \mathrm{ab}$ & $4.37 \pm 0.23 \mathrm{a}$ \\
\hline & & 78 & $4.34 \pm 0.14 \mathrm{ab}$ & $3.40 \pm 0.12 \mathrm{a}$ & $4.50 \pm 0.21$ & $4.60 \pm 0.24 \mathrm{~b}$ & $4.23 \pm 0.03 b$ & $4.50 \pm 0.23 \mathrm{ab}$ & $4.60 \pm 0.20 \mathrm{~b}$ & $4.50 \pm 0.21 \mathrm{~b}$ \\
\hline \multirow{6}{*}{ PJ } & \multirow{2}{*}{$25^{\circ} \mathrm{C}$} & 0 & $4.50 \pm 0.02 \mathrm{c}$ & $4.40 \pm 0.10 \mathrm{~b}$ & $4.41 \pm 0.04 \mathrm{~b}$ & $4.46 \pm 0.09 \mathrm{~b}$ & $4.44 \pm 0.30 \mathrm{~b}$ & $4.37 \pm 0.02 \mathrm{~b}$ & $4.46 \pm 0.11 \mathrm{~b}$ & $4.43 \pm 0.20 \mathrm{~b}$ \\
\hline & & 15 & $4.00 \pm 0.06 \mathrm{~b}$ & $3.78 \pm 0.22 \mathrm{a}$ & $3.75 \pm 0.16 \mathrm{a}$ & $3.63 \pm 0.23 \mathrm{a}$ & $3.62 \pm 0.02 \mathrm{ab}$ & $3.61 \pm 0.01 \mathrm{a}$ & $3.60 \pm 0.70 \mathrm{ab}$ & $3.59 \pm 0.02 \mathrm{a}$ \\
\hline & \multirow{4}{*}{$5^{\circ} \mathrm{C}$} & 15 & $4.05 \pm 0.28 \mathrm{a}$ & $4.15 \pm 0.12 \mathrm{a}$ & $4.20 \pm 0.32 b$ & $4.26 \pm 0.03 b$ & $4.27 \pm 0.33 b$ & $4.10 \pm 0.04 \mathrm{a}$ & $4.32 \pm 0.16 \mathrm{~b}$ & $4.08 \pm 0.14 \mathrm{a}$ \\
\hline & & 30 & $4.32 \pm 0.38 b$ & $3.83 \pm 0.59 \mathrm{a}$ & $4.11 \pm 0.15 b$ & $4.02 \pm 0.38 \mathrm{ab}$ & $3.99 \pm 0.06 \mathrm{ab}$ & $4.31 \pm 0.15 \mathrm{ab}$ & $4.17 \pm 0.04 \mathrm{ab}$ & $4.07 \pm 0.55 \mathrm{a}$ \\
\hline & & 45 & $4.30 \pm 0.11 \mathrm{~b}$ & $4.06 \pm 0.07 \mathrm{a}$ & $4.01 \pm 0.23 \mathrm{ab}$ & $3.94 \pm 0.05 \mathrm{ab}$ & $3.89 \pm 0.10 \mathrm{a}$ & $4.13 \pm 0.05 \mathrm{a}$ & $4.02 \pm 0.22 \mathrm{ab}$ & $3.96 \pm 0.22 \mathrm{a}$ \\
\hline & & 78 & $4.34 \pm 0.18 b$ & $4.00 \pm 0.10 \mathrm{a}$ & $3.95 \pm 0.18 b$ & $3.96 \pm 0.12 \mathrm{ab}$ & $3.89 \pm 0.13 \mathrm{a}$ & $4.04 \pm 0.08 \mathrm{a}$ & $3.98 \pm 0.10 \mathrm{a}$ & $4.00 \pm 0.29 \mathrm{a}$ \\
\hline
\end{tabular}

Values are expressed as the mean \pm S.D. of three determinations. Different letters in the same columns indicate significantly different $(\mathrm{p} \leq 0.05)$ values. 


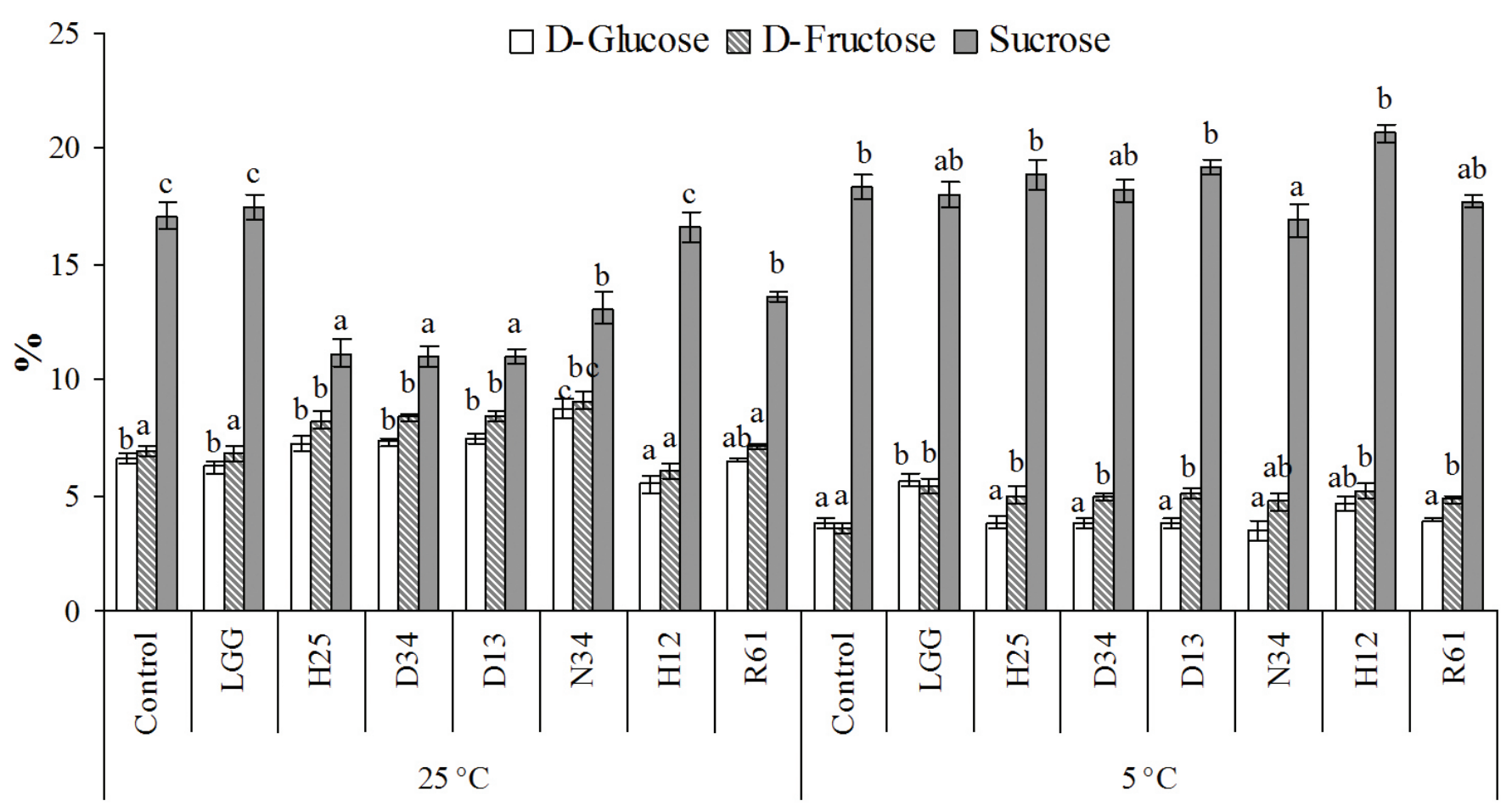

Figure 1. Sugar concentration in non-inoculated and inoculated Peach Jam (PJ) samples, after 78 days of storage at different temperatures, expressed as g/100 g of jam. The initial concentrations of sugars were: D-glucose $3.39 \mathrm{~g} / 100 \mathrm{~g}$; D-fructose $5.18 \mathrm{~g} / 100 \mathrm{~g}$; sucrose $19.21 \mathrm{~g} / 100 \mathrm{~g}$. Different letters indicate significantly different $(\mathrm{p} \leq 0.05)$ values among samples stored at 25 and $5{ }^{\circ} \mathrm{C}$, respectively.

At $5{ }^{\circ} \mathrm{C}$, all samples inoculated with the wild strains showed a decrease in total sugar value at the end of storage, except for the sample inoculated with $\mathrm{H} 12$, which had similar total sugar value compared with that of the control.

Evaluating the colour parameters, no significant difference was revealed between the control and the inoculated samples during storage at different temperatures, except for the sample inoculated with $\mathrm{H} 25$ strain which exhibited, at $25^{\circ} \mathrm{C}$, a higher yellow index (b parameter) than that of the control (data not shown). An increase in the browning parameters (absorbance at $420 \mathrm{~nm}$ ) was detected during storage for all inoculated samples, while in the control, the browning parameters remained unchanged throughout storage at both temperatures (data not shown).

\subsection{Survival of probiotic strains in PSM and PJ during storage}

The survival of probiotic bacteria during storage evaluated both in PSM and PJ at different temperatures is reported in Table 2 and expressed as mean count.

Non-inoculated PSM and PJ showed undetectable counts in MRS medium throughout storage at both temperatures (data not reported). In general, the results revealed different survival pattern of the LGG strain compared with that of the wild strains in both tested matrices and at both temperatures. In particular, during storage at $25^{\circ} \mathrm{C}$, PSM samples inoculated with wild strains H25, H12, D34, and D13 showed substantial increase up to 15 days, while the samples inoculated with strains R61 and N34 exhibited constant values (Table 2). From the $30^{\text {th }}$ day of storage, all PSM samples showed a significant decrease in viability remaining above the critical level of $10^{6} \mathrm{cfu} / \mathrm{g}$ for over 45 days. In contrast, PSM sample inoculated with LGG strain, despite its initial higher concentration, showed a significant decrease, reaching cell density of $10^{4} \mathrm{cfu} / \mathrm{g}$ up to 30 days of storage at $25^{\circ} \mathrm{C}$.

A different trend was observed at $5{ }^{\circ} \mathrm{C}$. In particular, all wild strains exhibited a significant decrease after 15 days of storage and a significant increase up to day 45 . Only the strain R61 was able to survive in the PSM after 78 days of storage. It is interesting to highlight that the LGG strain exhibited good viability up to 45 days of storage at $5{ }^{\circ} \mathrm{C}$ and a significant decrease at 78 days, still remaining above the critical level of $10^{6} \mathrm{cfu} / \mathrm{g}$.

While the LGG strain exhibited in PJ a trend similar to that observed in PSM samples during storage at 25 and $5{ }^{\circ} \mathrm{C}$, all wild strains showed variable viability with a substantial increase up to 15 days of storage at $25^{\circ} \mathrm{C}$, with cell density between $10^{10}$ to $10^{12} \mathrm{cfu} / \mathrm{g}$. All strains, except for H12, exhibited values above the critical level of $10^{6} \mathrm{cfu} / \mathrm{g}$ for over 45 days (Table 2). In the PJ samples stored at $5{ }^{\circ} \mathrm{C}$, all wild strains remained viable at levels greater than $10^{7} \mathrm{cfu} / \mathrm{g}$ throughout the storage period. In these conditions, the wild strains showed the highest concentrations (close to $10^{10} \mathrm{cfu} / \mathrm{g}$ ) between the $15^{\text {th }}$ and the $30^{\text {th }}$ day of storage, except for R61, which reached the highest concentration after 45 days of storage. 
Table 2. Mean counts (Log cfu/g) for lactic acid bacteria populations (in MRS agar) in control and inoculated Peach Synthetic Medium (PSM) and Peach Jam (PJ) stored at 25 and $5{ }^{\circ} \mathrm{C}$.

\begin{tabular}{|c|c|c|c|c|c|c|c|c|c|}
\hline & & Days & LGG & R61 & $\mathrm{H} 25$ & H12 & N34 & D34 & D13 \\
\hline \multirow{8}{*}{ PSM } & \multirow{5}{*}{$25^{\circ} \mathrm{C}$} & 0 & $8.74 \pm 0.61 \mathrm{~d}$ & $7.84 \pm 0.37 \mathrm{bc}$ & $7.69 \pm 0.67 c$ & $7.14 \pm 0.34 \mathrm{~b}$ & $7.30 \pm 0.55 b$ & $6.90 \pm 0.00 \mathrm{~b}$ & $6.00 \pm 0.00 \mathrm{~b}$ \\
\hline & & 15 & $8.18 \pm 0.76 \mathrm{~d}$ & $8.47 \pm 0.55 c$ & $8.30 \pm 0.05 \mathrm{~d}$ & $10.17 \pm 0.98 c$ & $7.30 \pm 0.28 b$ & $8.47 \pm 0.13 c$ & $9.30 \pm 0.30 \mathrm{~d}$ \\
\hline & & 30 & $4.04 \pm 0.38 \mathrm{c}$ & $7.20 \pm 0.28 b$ & $7.61 \pm 0.24 \mathrm{c}$ & $6.99 \pm 0.59 \mathrm{~b}$ & $7.40 \pm 0.45 b$ & $7.89 \pm 0.84 \mathrm{bc}$ & $7.87 \pm 0.23 c$ \\
\hline & & 45 & $2.00 \pm 0.76 \mathrm{~b}$ & $6.69 \pm 0.51 b$ & $6.95 \pm 0.28 b$ & $6.17 \pm 0.15 b$ & $6.41 \pm 0.88 \mathrm{~b}$ & $6.95 \pm 0.29 b$ & $7.30 \pm 0.76 \mathrm{c}$ \\
\hline & & 78 & $0.00 \pm 0.00 \mathrm{a}$ & $2.00 \pm 0.57 \mathrm{a}$ & $5.11 \pm 0.86 \mathrm{a}$ & $4.47 \pm 0.45 \mathrm{a}$ & $1.00 \pm 0.13 \mathrm{a}$ & $1.00 \pm 0.25 \mathrm{a}$ & $2.00 \pm 0.07 \mathrm{a}$ \\
\hline & \multirow{3}{*}{$5^{\circ} \mathrm{C}$} & 0 & $8.58 \pm 0.10 \mathrm{~b}$ & $7.84 \pm 0.13 \mathrm{~d}$ & $7.69 \pm 0.08 c$ & $7.14 \pm 0.20 \mathrm{c}$ & $7.30 \pm 0.10 \mathrm{c}$ & $6.90 \pm 0.09 b$ & $6.00 \pm 0.91 b c$ \\
\hline & & 45 & $8.20 \pm 0.43 b$ & $6.07 \pm 0.10 \mathrm{~b}$ & $6.41 \pm 0.78 \mathrm{ab}$ & $6.55 \pm 0.34 \mathrm{bc}$ & $5.69 \pm 0.76 \mathrm{~b}$ & $5.23 \pm 0.11 \mathrm{a}$ & $6.11 \pm 0.45 b c$ \\
\hline & & 78 & $6.50 \pm 0.19 \mathrm{a}$ & $6.78 \pm 0.70 c$ & $5.17 \pm 0.29 \mathrm{a}$ & $5.63 \pm 0.60 \mathrm{ab}$ & $2.69 \pm 0.55 \mathrm{a}$ & $5.14 \pm 0.03 \mathrm{a}$ & $1.00 \pm 0.05 \mathrm{a}$ \\
\hline \multirow{7}{*}{ PJ } & \multirow[b]{3}{*}{$25^{\circ} \mathrm{C}$} & 0 & $7.78 \pm 0.00 \mathrm{~d}$ & $7.50 \pm 0.34 \mathrm{~b}$ & $8.39 \pm 0.48 b$ & $7.69 \pm 0.12 b$ & $7.47 \pm 1.12 \mathrm{c}$ & $8.77 \pm 0.34 \mathrm{bc}$ & $8.35 \pm 0.66 \mathrm{bc}$ \\
\hline & & 15 & $8.48 \pm 0.87 \mathrm{~d}$ & $8.97 \pm 0.16 c$ & $10.37 \pm 0.87 \mathrm{c}$ & $12.14 \pm 0.90 \mathrm{~d}$ & $11.60 \pm 0.78 \mathrm{~d}$ & $10.43 \pm 0.52 c$ & $10.11 \pm 1.22 \mathrm{c}$ \\
\hline & & 30 & $5.88 \pm 1.25 c$ & $7.95 \pm 0.94 \mathrm{bc}$ & $14.22 \pm 1.43 \mathrm{~d}$ & $9.07 \pm 0.55 c$ & $8.14 \pm 0.90 \mathrm{c}$ & $9.51 \pm 1.88 \mathrm{bc}$ & $9.34 \pm 0.33 c$ \\
\hline & \multirow{4}{*}{$5^{\circ} \mathrm{C}$} & 15 & $8.55 \pm 0.39 b c$ & $9.73 \pm 0.24 \mathrm{c}$ & $8.00 \pm 0.87 \mathrm{ab}$ & $11.34 \pm 0.87 \mathrm{c}$ & $9.54 \pm 0.45 b$ & $9.96 \pm 0.99 b$ & $10.63 \pm 1.43 \mathrm{c}$ \\
\hline & & 30 & $8.90 \pm 0.10 c$ & $7.88 \pm 0.55 b$ & $12.12 \pm 1.18 \mathrm{c}$ & $10.27 \pm 0.95 c$ & $7.83 \pm 0.56 \mathrm{ab}$ & $11.02 \pm 1.89 \mathrm{~b}$ & $11.35 \pm 1.09 \mathrm{c}$ \\
\hline & & 45 & $7.38 \pm 0.60 \mathrm{ab}$ & $9.78 \pm 0.30 c$ & $9.44 \pm 0.34 b c$ & $8.83 \pm 0.60 \mathrm{~b}$ & $8.18 \pm 0.65 \mathrm{ab}$ & $8.27 \pm 0.56 \mathrm{a}$ & $10.44 \pm 0.87 \mathrm{c}$ \\
\hline & & 78 & $6.35 \pm 0.34 \mathrm{a}$ & $7.75 \pm 0.70 \mathrm{~b}$ & $7.80 \pm 0.23 \mathrm{a}$ & $7.81 \pm 0.90 \mathrm{ab}$ & $7.48 \pm 0.08 \mathrm{a}$ & $8.57 \pm 0.36 \mathrm{ab}$ & $7.80 \pm 0.36 \mathrm{a}$ \\
\hline
\end{tabular}

Values are expressed as the mean \pm S.D. of three determinations. Different letters in the same columns indicate significantly different ( $\mathrm{p} \leq 0.05)$ values.

\section{Discussion}

In Europe, neither a legal definition nor specific regulations governing probiotic food exist, and any bacterial strain of a known species that is traditionally used can be added to food. Probiotic products are usually marketed in the form of fermented milks and yoghurts; however, with an increase in the consumer vegetarianism throughout the developed countries, there is also an increasing demand for vegetarian probiotic products. Furthermore, lactose intolerance and the cholesterol content are two major drawbacks related to fermented dairy products (HEENAN et al., 2004; YOON; WOODAMS; HANG, 2004). Moreover, several studies have revealed that some commercial products do not sustain adequate populations of viable probiotic bacteria during their shelf life (DAVE; SHAH, 1997; SCHILLINGER, 1999). Recently, several raw materials have been investigated to determine whether they are suitable substances to produce novel non-dairy probiotic products (SHEEHAN; ROSS; FITZGERALD, 2007). It is noteworthy that many intrinsic and extrinsic properties of food, such as $\mathrm{pH}$, availability of nutrients, concentration of sugars (osmotic pressure), oxygen level, water activity, and storage temperature influence the viability of probiotic organisms (RIVERA-ESPINOZA; GALLARDO-NAVARRO, 2010; SHAH, 2000; CHAMPAGNE; RAYMOND; CAGNON, 2008).

In the present study, we investigated the survival of six wild strains in peach jam during storage at different temperatures. The strains were previously studied for probiotic properties, showing survival at $\mathrm{pH} 2.5$, good tolerance to different bile salt concentrations, susceptibility to several antibiotics, such as penicillin, ampicillin, tetracycline, chloramphenicol, and rifampicin, and antimicrobial activity against both Grampositive (Staphylococcus aureus, and Listeria monocytogenes) and -negative (Escherichia coli) bacteria (RANDAZZO; PITINO; CAGGIA, 2009; RANDAZZO et al., 2009). The strains also exhibited ability to adhere to both the intestinal epithelium cell line, Caco-2 cells, and to HT-29 cells, and survival capacity during in vitro dynamic gastrointestinal digestion with DGM using MRS broth medium and cheese as vehicles (PITINO et al., 2012; PITINO, 2010).

Results of the present study clearly demonstrate that the presumptive probiotic wild strains were able to survive in PJ during storage, highlighting that such medium could be a good candidate as vehicle of probiotics. The strains showed better survival ability in PJ than in the PSM, confirming that food formulation affects the viability of probiotics during storage (MATTILA-SANDHOLM et al., 2002; SAARELA et al., 2006). In the present study, the formulation of peach jam, which includes pectin and natural ingredients, seemed to better support the probiotic viability. This is in accordance with previous reports which asserted that solid matrices may protect bacteria during the storage of food (ONG; HENRIKSSON; SHAH, 2006; VINDEROLA; MOCCHIUTTI; REINHERMER, 2002).

Although lactobacilli have been considered as "difficult" microorganisms due to their demand for various essential aminoacids and vitamins (SALMINEN.; VON WRIGHT, 1993), some of them have been found able to survive in fruit matrices at refrigerated conditions (SHEEHAN; ROSS; FITZGERALD, 2007; SAARELA et al., 2006; CHAMPAGNE; GARDNER, 2008). Several studies have shown the survival of probiotic bacteria in matrices with high acidity and low $\mathrm{pH}$ during refrigerated storage $\left(4-5{ }^{\circ} \mathrm{C}\right)$ (YOON; WOODAMS; HANG, 2004; KYUNG; WOODAMS; HANG, 2005), asserting that growth and viability of cells in fruit and vegetables depend 
on the strains used. In our study, the high strain viability is in agreement with results obtained by other researchers, who reported that cells of probiotic strains, produced in different ways, had comparative stability in milk, whereas in juice, sucrose-protected cells survived better than in reconstituted skim-milk protected cells (SHAH, 2000; SAARELA et al., 2006).

As reported by other authors, the observed variations in strain stability may be due both to $\mathrm{pH}$ and storage temperatures. With respect to $\mathrm{pH}$, Champagne and co-workers (CHAMPAGNE; ROY; GARDNER, 2005) and Rivera-Espinoza and Gallardo-Navarro (2010) reported that in many fermented dairy-products, the loss of viability of probiotic bacteria is to be attributed to the decrease in $\mathrm{pH}$ values to $4-5$ and to the accumulation of organic acids as a result of growth and fermentation.

In the present study, probiotic strains showed good viability even at $\mathrm{pH}$ values lower than 4 , according to results reported by Sheehan and colleagues (SHEEHAN; ROSS; FITZGERALD, 2007), who found that the LGG strain was able to survive over 12 weeks at $4{ }^{\circ} \mathrm{C}$ in orange juice at $\mathrm{pH} 3.65$ and in pineapple juice at $\mathrm{pH}$ 3.4. In the present study, while the Lb. rhamnosus LGG strain was significantly affected by the higher temperature, almost all wild strains remained viable above the critical level in PJ at $25^{\circ} \mathrm{C}$ for 45 days. The relationship between $\mathrm{pH}$ values and viable counts showed that the viability of the LGG strain, in agreement with literature data, was strongly affected by the $\mathrm{pH}$ reduction (SHAH, 2000; SHAH; JELEN, 1990; KAILASAPATHY; HARMOSTORF; PHILLIPS, 2008), while the viability of the wild strains was less affected.

Moreover, results point out a slight decrease in sucrose and an increase in glucose and fructose concentrations during storage at $25{ }^{\circ} \mathrm{C}$. The sucrose decrease could be due to two phenomenons occurring simultaneously: bacterial intracellular accumulation and sugar inversion. Sunny-Roberts and Knorr (SUNNY-ROBERTS; KNORR, 2008), evaluating the response of Lb. rhamnosus to sucrose-induced osmotic stress, demonstrated that cells survived the osmotic stress by accumulating sucrose at intracellular level, whereas the detected increase in both glucose and fructose is the result of the inversion of sucrose, which indeed is accelerated in the acidic conditions of the matrix and especially at the higher storage temperature. Jams and marmalades are often wrongly believed to be stable products (LICCIARDELLO; MURATORE, 2011); nevertheless, due to their high sugar content, low water activity, and low $\mathrm{pH}$, they are ideal matrices for sugar degradation reactions (MURATORE et al., 2006).

Results of the present study revealed no significant difference between the colour parameters of the control and that of the inoculated jam samples during storage at different temperatures, in agreement with previous results which reported that, in general, probiotic cultures do not tend to strongly modify the sensorial properties of the products to which they are added (CHAMPAGNE; GARDNER, 2008). Considering taste as the primary driver for food selection, followed by health considerations (LUCKOW; DELAHUNTY, 2004), the effects of probiotic added to jam need to be further investigated.

\section{Conclusion}

In the present study, the survival of $L b$. rhamnosus probiotic strains in peach jam was reported for the first time. The viability of six probiotic wild strains was evaluated in a fruit-based medium and in peach jam at different storage temperatures in comparison with a type strain (LGG), widely used as probiotic. All strains exhibited better performances in PJ samples, and the tested $L b$. rhamnosus wild strains highlighted a better survival performance at both storage temperatures compared with that of the type strain, exhibiting counts higher than $7 \mathrm{Log} \mathrm{cfu} \mathrm{g}^{-1}$ up to 78 days of storage at $5{ }^{\circ} \mathrm{C}$. During storage at $25^{\circ} \mathrm{C}$, most strains in PJ maintained viable counts, which were above the critical level for 45 days. The probiotic cultures added to the jam did not significantly modify the colour parameters of the produce; however the metabolism of lactobacilli does cause changes in the $\mathrm{pH}$ which, in turn, accelerates the rate of hydrolisis of sucrose into monosaccharides. In addition, the intracellular sucrose accumulation as a response to osmoti stress could explain, in part, the sucrose reduction, although this hypothesis deserves further investigation.

Peach jam might be a good candidate for producing a novel and tasty functional, non-dairy, probiotic food which could effectively deliver probiotic $L b$. rhamnosus strains either at refrigerated conditions or at room temperature. A daily intake of about 10 grams of jam could supply from $10^{8}$ to $10^{9}$ viable probiotic cells, using preparations stored for 45 days and for 78 days at room temperature and refrigerated conditions, respectively. These values are comparable with those found in milk-based probiotic products, containing more than $10^{6}$ probiotic bacteria per $\mathrm{ml}$ at the end of their shelf life ( $\leq 30$ days at refrigerated conditions).

From an industrial point of view, the variability in survival at different storage temperatures should be considered as a major criterion for the selection of strains to be used in probiotic jams stored at refrigerated or room temperature.

\section{Acknowledgements}

The authors would like to thank Prof. Raffaele Coppola for providing some of the screened strains. This study was financially supported by the University of Catania (Progetti di Ateneo) "Studio delle caratteristiche tecnologiche di ceppi di Lactobacillus rhamnosus per la formulazione di nuovi alimenti probiotici”.

\section{References}

BERNI-CANANI, R. et al. Probiotics for treatment of acute diarrhea in children: randomized clinical trail of five different preparations. BMJ, v. 335, 340-342, 2007. PMid:17690340 PMCid:PMC1949444. http://dx.doi.org/10.1136/bmj.39272.581736.55

CHAMPAGNE, C. P.; GARDNER, N. J. Effect of storage in a fruit on subsequent survival of probiotic lactobacilli to gastro-intestinal stresses. Food Research International, v. 41, p. 539-543, 2008. http://dx.doi.org/10.1016/j.foodres.2008.03.003

CHAMPAGNE, C. P.; RAYMOND, Y.; CAGNON, R. Viability of Lactobacillus rhamnosus R0011 in an apple-based fruit juice under simulated storage conditions at the consumer level. Journal of Food 
Science, v. 73, p. 221M-226M, 2008. PMid:18577004. http://dx.doi. org/10.1111/j.1750-3841.2008.00775.x

CHAMPAGNE, C. P.; ROY, D.; GARDNER, N. J. Challenges in addition of probiotic cultures to foods. Critical Reviews in Food Science and Nutrition, v. 4, p. 61-84, 2005. PMid:15730189. http://dx.doi. org/10.1080/10408690590900144

CORBO, M. R. et al. Microbiological and biochemical properties of Canestrato Pugliese hard cheese supplemented with bifidobacteria. Journal of Dairy Science, v. 84, p. 551-561, 2001. http://dx.doi. org/10.3168/jds.S0022-0302(01)74507-9

CROSS, M. L.; STEVENSON, L. M.; GILL, H. S. Anti-allergy properties of fermented food: an important immunoregulatory mechanism of lactic acid bacteria. International Immunopharmacology, v. 1, p. 891-901, 2001. http://dx.doi.org/10.1016/S1567-5769(01)00025-X

CRUZ, A. G. et al. Ice-cream as a probiotic food carrier. Food Research International, v. 42, p. 1233-1239, 2009. http://dx.doi.org/10.1016/j. foodres.2009.03.020

DAVE, R. I.; SHAH, N. P. Viability of yoghurt and probiotic bacteria in yoghurts made from commercial starter cultures. International Dairy Journal, v. 7, p. 31-41, 1997. http://dx.doi.org/10.1016/ S0958-6946(96)00046-5

DE VUYST, L.; AVANTI, L.; MAKRAS, E. Probiotics, prebiotics and gut health. In: REMACLE, C.; REUSENS, B. (Eds.). Functional Foods, Ageing and Degenerative Disease. Cambrige: Wood-head Publishing Ltd., 2004, p. 416-482. http://dx.doi. org/10.1533/9781855739017.3.416

DING, W. K.; SHAH, N. P. Acid, bile, and heat tolerance of free and microencapsulated probiotic bacteria. Journal of Food Science, v. 72, p. 446-450, 2007. PMid:18034741. http://dx.doi.org/10.1111/ j.1750-3841.2007.00565.x

EUROPEAN FOOD SAFETY AUTHORITY - EFSA. Qualified presumption of safety. The EFSA Journal, v. 587, p. 4-6, 2007. Appendix A- Scientific Report on the Assessment of gram positive non sporuling bacteria.

FOOD AND AGRICULTURE ORGANIZATION - FAO; WORLD HEALTH ORGANIZATION - WHO. Guidelines for the Evaluation of Probiotic in Food: Report of a Joint FAO/WHO Working Group on Drafting Guidelines for the Evaluation of Probiotics in Food. London: FAO/WHO, 2002.

HEENAN, C. N. et al. Survival and sensory acceptability of probiotic microorganisms in a non-fermented frozen vegetarian dessert. Lebensmittel Wissenschaft Und Technologie, v. 37, p. 461-466, 2004.

KAILASAPATHY, K.; HARMOSTORF, I.; PHILLIPS, M. Survival of Lactobacillus acidophilus and Bifidobacterium animalis ssp. lactis in stirred fruit yogurts. Lebensmittel Wissenschaft Und Technologie, v. 41, p. 1317-1322, 2008.

KYUNG, Y. Y.; WOODAMS, E. E.; HANG, Y. D. Fermentation of beet juice by beneficial lactic acid bacteria. Lebensmittel Wissenschaft Und Technologie, v. 38, p. 73-75, 2005.

LAROIA, S.; MARTIN, J. H. Effect of $\mathrm{pH}$ on survival of Bifidobacterium bifidum and Lactobacillus acidophilus in frozen fermented dairy desserts. Cultured Dairy Products Journal, v. 26, p. 13-21, 1991.

LAVERMICOCCA, P. Highlights on new food research. Digestive and Liver Disease, v. 38, p. S95-S299, 2006. http://dx.doi.org/10.1016/ S1590-8658(07)60014-0

LICCIARDELLO, F.; MURATORE, G. Effect of temperature and some added compounds on the stability of blood orange marmalade. Journal of Food Science, v. 76, n. 7, p. C1094-C1100,
2011. PMid:22417545. http://dx.doi.org/10.1111/j.17503841.2011.02335.x

LOURENS-HATTINGH, A.; VILJOEN, B. C. Growth and survival of a probiotic yeast in dairy products. Food Research International, v. 34, p. 791-796, 2001. http://dx.doi.org/10.1016/S09639969(01)00085-0

LUCKOW, T.; DELAHUNTY, C. Which juice is healthier? A consumer study of probiotic non-dairy juice drinks. Food Quality and Preference, v. 15, p. 751-759, 2004. http://dx.doi.org/10.1016/j. foodqual.2003.12.007

MATTIA, A.; MERKER, R. Regulation of probiotic substances as ingredients in foods: pre-market approval or "Generally Recognized as Safe" notification. Clinical Infectious Diseases, v. 46, p. S115-S118, 2008. PMid:18181714. http://dx.doi. org/10.1086/523329

MATTILA-SANDHOLM, T. et al. Technological challenges for future probiotic foods. International Dairy Journal, v. 12, p. 173-182, 2002. http://dx.doi.org/10.1016/S0958-6946(01)00099-1

McFARLAND, L. V. Meta-analysis of probiotics for the prevention of traveller's diarrhoea. Travel Medicine and Infectious Disease, v. 5, p. 97-105, 2007. PMid:17298915. http://dx.doi.org/10.1016/j. tmaid.2005.10.003

MORENO, M. R. F. et al. The role and application of enterococci in food and health. International Journal of Food Microbiology, v. 106, p. 1-24, 2006. PMid:16216368. http://dx.doi.org/10.1016/j. ijfoodmicro.2005.06.026

MURATORE, G. et al. Role of different factors affecting the formation of 5-hydroxymethyl-2-furancarboxaldehyde in heated grape must. Journal of agricultural and food chemistry, v. 54, p. 860-863, 2006. http://dx.doi.org/10.1021/jf051786t

ONG, L.; HENRIKSSON, A.; SHAH, N. P. Development of probiotic cheddar cheese containing Lactobacillus acidophilus, Lb. casei, Lb. paracasei and Bifidobacterium spp. and the influence of these bacteria on proteolytic patterns and production of organic acid. International Dairy Journal, v. 16, p. 446-456, 2006. http://dx.doi. org/10.1016/j.idairyj.2005.05.008

OUWEHAND, A. C.; SALMINEM, S. J. The health effects of cultured milk products with viable and non-viable bacteria. International Dairy Journal, v. 8, p. 749-758, 1998. http://dx.doi.org/10.1016/ S0958-6946(98)00114-9

PENNA, A. L. B.; RAO-GURRAM, S.; BARBOSA-CÁNOVAS, G. V. Effect of milk treatment on acidification, physicochemical characteristics, and probiotic cell counts in low fat yogurt. Milchwissenschaft, v. 62, p. 48-52, 2007.

PITINO I. et al. Survival of Lactobacillus rhamnosus strains inoculated in cheese matrix during simulated human digestion. Food Microbiology, v. 31, p. 57-63, 2012. PMid:22475943. http://dx.doi. org/10.1016/j.fm.2012.02.013

PITINO, I. Survival of Lactobacillus rhamnosus strains in the upper gastrointestinal tract. Food Microbiology, v. 27, p. 1121-1127, 2010. PMid:20832693. http://dx.doi.org/10.1016/j.fm.2010.07.019

PITINO, I. et al. Il pecorino tradizionale come fonte di microrganismi probiotici. Scienza e Tecnica Lattiero Casearia, v. 60, p. 1-7, 2009.

RANDAZZO, C. L.; PITINO, I.; CAGGIA, C. Sicurezza dei ceppi probiotici. Il Latte, v. 7, p. 40-43, 2009.

RANDAZZO, C. L. et al. Pecorino Crotonese cheese: study of bacterial population and flavour compounds. Food Microbiology, v. 27, 363-374, 2009. PMid:20227601. http://dx.doi.org/10.1016/j. fm.2009.11.010 
RESTUCCIA, C. et al. Biological control of peach fungal pathogens by commercial products and indigenous yeasts. Journal of Food Protection, v. 69, p. 2465-2470, 2006. PMid:17066929.

RIVERA-ESPINOZA, Y.; GALLARDO-NAVARRO, Y. Non-dairy probiotic products. Food Microbiology, v. 27, p. 1-11, 2010. PMid:19913684. http://dx.doi.org/10.1016/j.fm.2008.06.008

SAARELA, M. et al. Gut bacteria and health foods - the European perspective. International Journal of Food Microbiology, v. 78, p. 99-117, 2002. http://dx.doi.org/10.1016/S0168-1605(02)00235-0

SAARELA, M. et al. Stability and functionality of freeze-dried probiotic Bifidobacterium cells during storage in juice and milk. International Dairy Journal, v. 16, p. 121477-121482, 2006. http:// dx.doi.org/10.1016/j.idairyj.2005.12.007

SALMINEN, S.; VON WRIGHT, A. Lactic Acid Bacteria. New York: Marcel Dekker Inc, 1993.

SALMINEN, S. et al. Demonstration of safety of probiotics. International Journal of Food Microbiology, v. 44, p. 93-106, 1998. http://dx.doi.org/10.1016/S0168-1605(98)00128-7

SANDERS, M. E.; HIUS IN'T VELD, J. Bringing a probioticcontaining functional food to the market: microbiological, product, regolatory and labeling issues. Antonie van Leeuwenhoek Journal of Microbiology, v. 76, p. 293-315, 1999. http://dx.doi. org/10.1023/A:1002029204834

SCHILLINGER, U. Isolation and identification of lactobacilli from novel-type probiotic and mild yoghurts and their stability during refrigerated storage. International Journal of Food Microbiology, v. 47, p. 79-87, 1999. http://dx.doi.org/10.1016/ S0168-1605(99)00014-8

SCHREZENMEIR, J.; DE VRESE, M. Probiotics, prebiotics, and symbiotics - approaching a definition. American Journal of Clinical Nutrition, v. 77, p. 361-364, 2001.
SHAH, N. P. Probiotic bacteria: selective enumeration and survival in dairy foods. Journal of Dairy Science, v. 83, p. 894-907, 2000. http://dx.doi.org/10.3168/jds.S0022-0302(00)74953-8

SHAH, N. P.; JELEN, P. Survival of lactic acid bacteria and their lactases under acidic conditions. Journal of Food Science, v. 55, p. 506-509, 1990. http://dx.doi.org/10.1111/j.1365-2621.1990.tb06797.x

SHEEHAN, V. M.; ROSS, P.; FITZGERALD, G. F. Assessing the acid tolerance and the technological robustness of probiotic cultures for fortification in fruit juices. Innovative Food Science and Emerging Technologies, v. 8, p. 279-284, 2007. http://dx.doi.org/10.1016/j. ifset.2007.01.007

SUNNY-ROBERTS, E. O.; KNORR, D. Evaluation of the response of Lactobacillus rhamnosus VTT E-97800 to sucrose-induced osmotic stress. Food Microbiology, v. 25, p. 183-189, 2008. PMid:17993393. http://dx.doi.org/10.1016/j.fm.2007.05.003

TAMIME, A. Y. Fermented milks: a historical food with modern applications. European Journal of Clinical Nutrition, v. 56, p. S2-S15, 2002. PMid:12556941. http://dx.doi.org/10.1038/ sj.ejcn. 1601657

VANCANNEYT, H. et al. Intra-specific genotypic characterization of Lactobacillus rhamnosus strains intended for probiotic use and isolates of human origin. Applied and Environmental Microbiology, v. 72, p. 5376-5383, 2006. PMid:16885289 PMCid:PMC1538751. http://dx.doi.org/10.1128/AEM.00091-06

VINDEROLA, C. G.; MOCCHIUTTI, P.; REINHERMER, J. A. Interactions among lactic acid starter and probiotic bacteria used for fermented dairy products. Journal of Dairy Science, v. 85, p. 721729, 2002. http://dx.doi.org/10.3168/jds.S0022-0302(02)74129-5

YOON, K. Y.; WOODAMS, E. E.; HANG, Y. D. Probiotication of tomato juice by lactic acid bacteria. Journal of Microbiological, v. 42, p. 315-318, 2004. PMid:15650688. 